University of Nebraska - Lincoln

DigitalCommons@University of Nebraska - Lincoln

USDA National Wildlife Research Center - Staff Publications
U.S. Department of Agriculture: Animal and Plant Health Inspection Service

2017

\title{
DiazaCon reduces black-tailed prairie dog reproduction in Colorado
}

Christi A. Yoder

USDA-APHIS-Wildlife Services

Richard E. Mauldin

USDA/APHIS/WS/National Wildlife Research Center

James P. Gionfriddo

USDA/APHIS/WS/National Wildlife Research Center

Kenneth A. Crane

USDA/APHIS/WS/National Wildlife Research Center

David A. Goldade

USDA/APHIS/WS/National Wildlife Research Center

See next page for additional authors

Follow this and additional works at: https://digitalcommons.unl.edu/icwdm_usdanwrc

Part of the Life Sciences Commons

Yoder, Christi A.; Mauldin, Richard E.; Gionfriddo, James P.; Crane, Kenneth A.; Goldade, David A.; and Engeman, Richard M., "DiazaCon reduces black-tailed prairie dog reproduction in Colorado" (2017). USDA National Wildlife Research Center - Staff Publications. 1922.

https://digitalcommons.unl.edu/icwdm_usdanwrc/1922

This Article is brought to you for free and open access by the U.S. Department of Agriculture: Animal and Plant Health Inspection Service at DigitalCommons@University of Nebraska - Lincoln. It has been accepted for inclusion in USDA National Wildlife Research Center - Staff Publications by an authorized administrator of DigitalCommons@University of Nebraska - Lincoln. 


\section{Authors}

Christi A. Yoder, Richard E. Mauldin, James P. Gionfriddo, Kenneth A. Crane, David A. Goldade, and Richard M. Engeman 


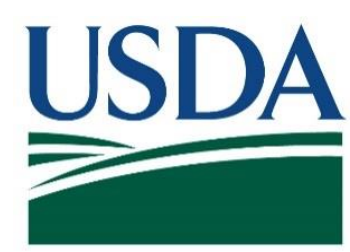

U.S. Department of Agriculture

U.S. Government Publication

Animal and Plant Health Inspection Service

Wildlife Services 


\title{
DiazaCon reduces black-tailed prairie dog reproduction in Colorado
}

\author{
Christi A. Yoder ${ }^{\mathrm{A}}$, Richard E. Mauldin ${ }^{\mathrm{A}} \mathrm{B}$, James P. Gionfriddo ${ }^{\mathrm{A}}$, Kenneth A. Crane $^{\mathrm{A}}$, \\ David A. Goldade ${ }^{\mathrm{A}}$ and Richard M. Engeman ${ }^{\mathrm{A}}$ \\ AUSDA/APHIS/WS/National Wildlife Research Center, 4101 LaPorte Avenue, Fort Collins, CO 80521, USA. \\ ${ }^{B}$ Corresponding author. Email: Richard.E.Mauldin@aphis.usda.gov
}

\begin{abstract}
Context. Black-tailed prairie dogs (Cynomus ludovicianus) often come into conflict with humans in urban natural areas adjacent to private property by destroying plants and denuding the landscape. There is a diversity of attitudes related to urban prairie dog management in Colorado and interest in non-lethal methods is increasing. Therefore, the development of non-lethal methods that allow the existence of prairie dogs and mitigate damage related to population density is needed.

Aims. The efficacy of DiazaCon (20,25-diazacholesterol dihydrochloride, a cholesterol analogue) as an oral contraceptive bait for reducing reproduction in black-tailed prairie dogs was tested. Persistence of DiazaCon in black-tailed prairie dogs 11 months after initial application was also determined.

Methods. Prairie dogs were baited with DiazaCon-coated rolled oats or control bait for 10 days over a 20-day period in November 2007 on one control and one treatment site. Sites were randomly assigned to a treatment group. Visual counts were used 8 months post-treatment (June/July 2008) to determine pup : adult ratios on both sites. Prairie dogs on both sites were trapped 11 months post-treatment (September/October 2008) to gather mass and age data to assess juvenile : adult ratios and to collect blood samples for determination of serum cholesterol and desmosterol concentrations.

Key results. DiazaCon treatment reduced the number of pups per adult by $95.5 \%$ when compared with the control site in June/July $2008(0.09 \pm 0.02, n=10$, number of observation days) versus $2.0 \pm 0.2(n=10)$. Free serum cholesterol levels in treated animals $\left(370.7 \mu \mathrm{g} \mathrm{mL}^{-1}\right)$ were lower than control animal levels $\left(411.6 \mu \mathrm{g} \mathrm{mL}^{-1}, P<0.015\right)$, while treated desmosterol levels $\left(14.5 \mu \mathrm{g} \mathrm{mL}^{-1}\right)$ were higher than controls $\left(0.35 \mu \mathrm{g} \mathrm{mL}^{-1}, P<0.02\right) 11$ months after ingestion of DiazaCon bait. However, these differences would likely not have been sufficient to prevent successful breeding in the upcoming breeding season.

Conclusions. DiazaCon is an effective contraceptive in black-tailed prairie dogs. It is probably reversible and will likely affect breeding success for only one breeding season. DiazaCon may provide an additional tool to help manage urban populations of prairie dogs in locations where lethal control is unacceptable.

Implications. The need for further research into secondary hazards to non-target animals, such as predators, is discussed. Recommendations for field application are also discussed.
\end{abstract}

Additional keywords: contraception, Cynomys ludovicianus, population reduction, reproduction, 20,25-diazacholesterol dihydrochloride.

Received 6 November 2015, accepted 19 November 2016, published online 13 February 2017

\section{Introduction}

Black-tailed prairie dogs (Cynomus ludovicianus) are one of five species of prairie dogs found in North America. Their distribution covers the Great Plains from northern Mexico to southern Canada. Although they currently occupy less than $2 \%$ of their original range (Miller et al. 1990, 1994, 2000), they are frequently the subject of controversy. Prairie dogs are considered a keystone species in the mixed-grass ecosystem, having numerous positive interactions with other plant and animal species (Kotliar et al. 1999). Their burrows aerate the soil and provide shelter for other wildlife, and they serve as prey for a wide variety of predators (Graves 2001). Human attitudes towards prairie dogs vary widely, from great appreciation and interest in urban residents to a more antagonistic, low-concern view in rural, largely livestock-dependent areas (Lybecker et al. 2002).

Because of the limited opportunities for dispersal in urban environments, prairie dogs can exist there in densities up to five times higher than in rural environments, which can lead to conflicts with humans (Johnson and Collinge 2004; Magle et al. 2007). In urban and suburban environments, conflicts stem from degradation of habitats through burrowing and grazing, damage to ornamental vegetation, and the spread of colonies into human neighbourhoods (Hygnstrom and Virchow 1994; Zinn and Andelt 1999; Witmer et al. 2000).

Prairie dog habitat along the Front Range in Colorado is highly fragmented and many urban colonies exist in small natural areas 
(Magle and Crooks 2009). Some of these areas are officially designated as natural areas by municipalities, and others exist in highway rights-of-way or vacant lots. Management of urban and suburban prairie dogs is highly controversial, and municipalities are charged with maintaining colonies while minimising damage associated with overgrazing and colony expansion (Witmer et al. 2000).

In 1991, prairie dog populations in Fort Collins, Colorado occupied $\sim 836 \mathrm{ha}, 82 \%$ of which occurred in designated natural areas (Fort Collins Natural Resources Division 1998). A survey of Fort Collins residents in 1993 showed that residents who experienced no prairie dog-related damage supported relocation over lethal control. Residents who experienced conflicts with prairie dogs were more likely to support lethal control measures (Zinn and Andelt 1999). Both groups of stakeholders were willing to support a combination of control and preservation, rating protection of property and the presence of raptors as important outcomes of management. Because of the diverse attitudes related to prairie dog management, nonlethal methods that allow the existence of prairie dogs but help reduce damage related to population growth are needed.

Management of prairie dogs has included lethal control such as poisoning and fumigation, and non-lethal measures such as barriers and relocation (Franklin and Garrett 1989; Robinette et al. 1995; Andelt and Hopper 1998). Poisoning, while potentially effective, is frequently restricted or regulated and may pose hazards to pets, children and non-target species. The use of toxicants and fumigants can be very controversial, especially in urban-suburban settings, and is prohibited in many contexts (Witmer et al. 2000). Barriers and relocation tend to be expensive, are not always effective, are dependent on available sites and, in the case of some relocations, can be highly detrimental to both transplants and conspecifics at the transplant site (Franklin and Garrett 1989; Hygnstrom 1996; Truett et al. 2001; Witmer et al. 2008, Massei et al. 2010). The cost of control can outweigh the benefits (Collins et al. 1984). Survival and reproductive rates increase after a population declines, whether caused by human-initiated lethal measures or by natural factors such as plague outbreaks (Knowles 1986; Cully 1997).

Contraception is a non-lethal management technique that could help reduce the growth of prairie dog colonies. One promising oral contraceptive agent, DiazaCon $(20,25-$ diazacholesterol dihydrochloride), prevents the conversion of desmosterol to cholesterol by inhibiting the $\Delta_{24}$-reductase enzyme (Emmons et al. 1982; Yoder et al. 2004). Cholesterol is essential for reproduction because it is needed for the production of pregnenolone, the precursor hormone to progesterone, oestradiol and testosterone. Progesterone and oestradiol are needed for ovarian follicular development and ovulation, and testosterone is necessary for sperm production. Reducing cholesterol reduces reproductive steroid hormone synthesis, thereby decreasing reproduction (Yoder et al. 2004). Concomitant with decreased cholesterol is an increase in desmosterol, which can be used as a biomarker of DiazaCon consumption (Johnston et al. 2003).

Yoder et al. (2011) gavaged grey squirrels (Sciurus carolinensis) for two days with aqueous DiazaCon solutions (either 50 or $100 \mathrm{mg} \mathrm{m}^{-1}$ ), followed by feeding them
DiazaCon-coated peanuts for 8 days with target doses of either 50 or $100 \mathrm{mg} \mathrm{kg}^{-1}$. Serum cholesterol was significantly reduced by $\geq 40 \%$ when compared with controls for 2 months following administration in both treatment groups, indicating that squirrels would likely have been contracepted. Nash et al. (2006) reported prairie dogs treated with 30-45 mg DiazaCon per kg body mass for 10 days spread out over a 3 -week period exhibited a $41 \%$ decrease in plasma cholesterol concentrations and a $47 \%$ decrease in reproduction (juveniles/adult). Treatment of prairie dogs began immediately before the breeding season, which runs from February to March. It is likely that earlier treatment with DiazaCon would have had a greater inhibitory effect (Nash et al. 2006). Therefore, we conducted a study that implemented an earlier treatment date.

This study had three objectives, to determine: (1) the efficacy of DiazaCon for the reproductive control of blacktailed prairie dogs; (2) the effect on contraceptive efficacy of starting treatment before the breeding season; and (3) whether the effects of DiazaCon administration persist in animals 11 months after treatment.

\section{Materials and methods}

The experimental protocol (QA-1388) describing this study was reviewed and approved by the National Wildlife Research Center's Animal Care and Use Committee and complied with the Animal Welfare Act.

\section{Study area}

The study area was located $\sim 4.5 \mathrm{~km}$ south-west of Fort Collins, Colorado at a natural area maintained by the City of Fort Collins. The area encompassed $\sim 452$ ha of shortgrass prairie and foothills shrubland with several kilometres of hiking trails available to the public. Off-trail access by the public was prohibited. Both control and treatment sites were located at this area. A customized SAS statistical program was used to randomly assign the two sites to either the treatment or control group (SAS Institute Inc. 2003).

The control site was 3.3 ha and the treatment site was 4.1 ha (Fig. 1) and the two sites were $113.1 \mathrm{~m}$ apart. Within both control and treatment sites, two 1-ha plots (named north and south) were delineated using stakes with fluorescent orange or pink flagging to make a total of four plots.

\section{Bait manufacture and site baiting}

Batches of treatment bait were manufactured using rolled oats, molasses $\left(3.5 \% \mathrm{w} \mathrm{w}^{-1}\right)$ and DiazaCon $\left(0.22 \% \mathrm{w} \mathrm{w}^{-1}\right)$. Control bait was produced in the same manner, omitting DiazaCon. A $50 \mathrm{~g}$ subsample of each batch of bait was removed and stored at $-70^{\circ} \mathrm{C}$ until analysed for DiazaCon content. The bait was either used the day it was manufactured or stored for $<2$ weeks at $4^{\circ} \mathrm{C}$ until needed.

Prairie dogs were pre-baited with control bait for 6 days over an 8-day period in early November 2007. Approximately $22.5 \mathrm{~g}$ bait ( $\sim 0.25$ cup) was placed on the burrow mound just outside the entrance of all active burrows. Since a single prairie dog can maintain up to five burrows (Hoogland 1995), baiting all active burrows was necessary to assure complete exposure to the bait. At the end of the pre-baiting period, treatment began 


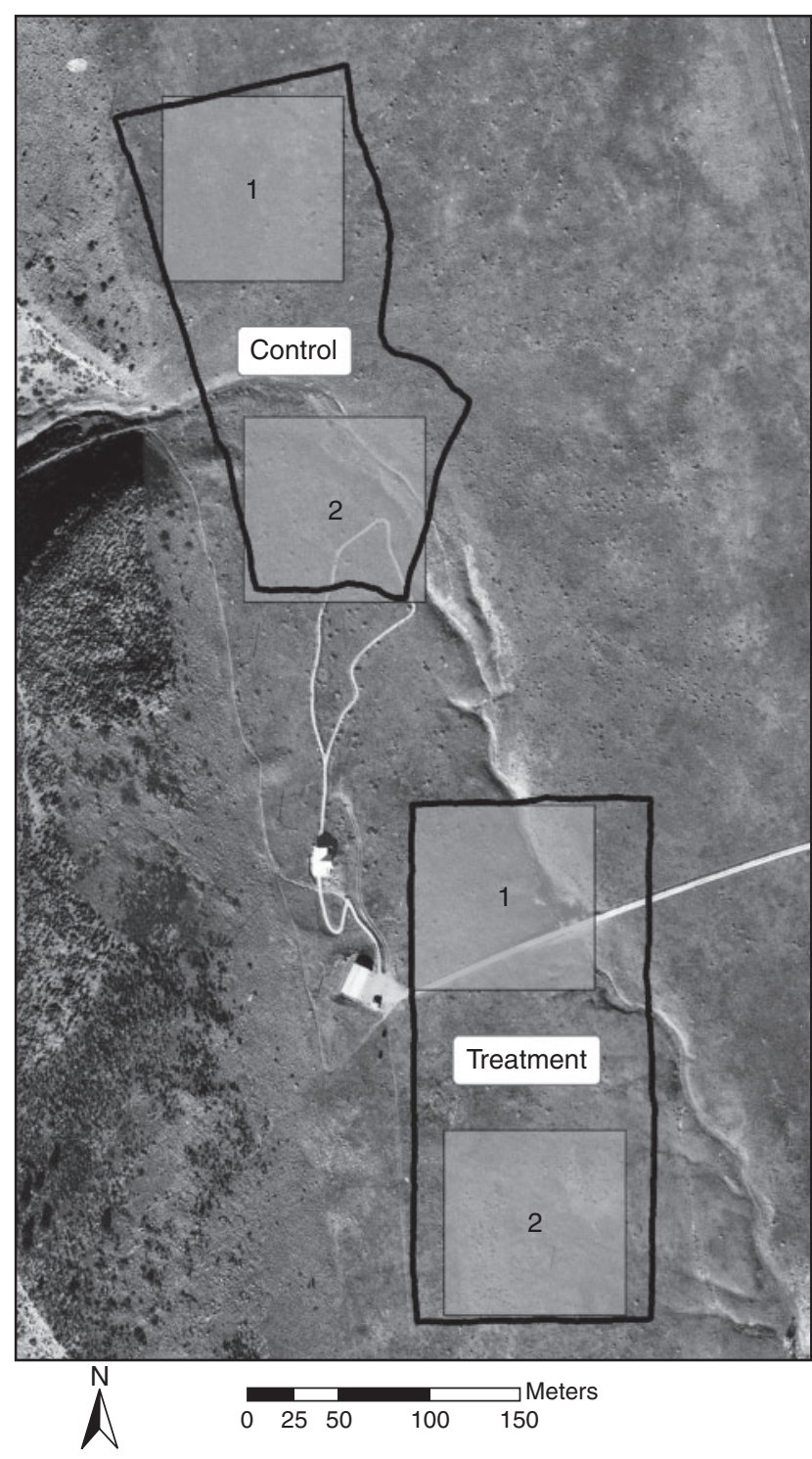

Fig. 1. Aerial map of experimental site showing control and treatment plots.

and $\sim 22.5 \mathrm{~g}$ of either control or treated bait was placed on the active mounds. No baiting occurred on days when prairie dogs were unlikely to come above ground (e.g. raining, snowing, temperature $<0^{\circ} \mathrm{C}$ ). Baiting occurred on 10 days over a 20-day period. The target dose was $50 \mathrm{mg}$ DiazaCon $\mathrm{kg}^{-1}$ body mass day ${ }^{-1}$ for each animal and was based on an average body mass of $1 \mathrm{~kg}$ and consumption of $\sim 22.5 \mathrm{~g}$ of bait day ${ }^{-1}$.

\section{Visual obstruction assessment}

Visual counting began in mid-June 2008 when pups (juveniles recently emerged from the burrows) were easily visible. An estimate of visual obstruction (the percentage of each colony that could not be seen from the counting position; Menkens et al. 1990) was obtained and used in adjusting visual pup counts for each observer as described below for both the treatment and control sites. A known number of $1 \mathrm{~L}$ plastic bottles were painted light brown and placed in both systematic and random patterns throughout each site. Random placement entailed placing bottles on prairie dog mounds, near clusters of mounds and in a random (not equally spaced) distribution across the plot. Systematic placement was defined as placing bottles on linear transects with prairie dog mounds somewhat influencing the location of transect lines. Transect lines were parallel to each other and placed in a straight line such that the maximum number of prairie dog burrows would be close to each line. A grid system was not used for the placement of transect lines because newly emerged pups were most likely to stay close to their burrows. Observers were not present for the placement of the bottles.

Using binoculars, two observers counted bottles at each site three times (Severson and Plumb 1998) for each pattern of bottle placement (e.g. three times for random placement and three times for systematic placement). The counts were averaged for each site and visual obstruction was estimated using the following equation:

$$
\begin{aligned}
\text { Visual obstruction }= & 1-(\text { bottles counted }) / \\
& (\text { actual number of bottles })
\end{aligned}
$$

Visual obstruction was determined separately for the control and treated sites.

\section{Visual prairie dog counts}

Visual prairie dog counts were adjusted for visual obstruction using the following equation (Menkens et al. 1990):

$$
\begin{aligned}
\text { adjusted count }= & (\text { actual count }) / \\
& (1-(\text { visual obstruction } / 100))
\end{aligned}
$$

Counts of pups and adults were conducted using binoculars on five consecutive weekdays in June and July 2008. All counts occurred on sunny or slightly overcast days with no precipitation. Counts were performed from $\geq 30 \mathrm{~m}$ outside the boundaries of the treatment and control plots to reduce disturbances.

Arrival of personnel at the study site between 0830 and 0900 hours invariably resulted in animals seeking refuge in their burrows, so counting did not commence until prairie dog activity resumed $(\sim 30 \mathrm{~min})$. To count the animals, plots were scanned starting at one end of the plot and proceeding to the other end. The total number of animals seen and the number of adults, pups, or unknown-aged prairie dogs was recorded. To avoid double counting, observers did not go back over any section during a count. Observers then waited $15 \mathrm{~min}$ before beginning the next count. Family group (coterie) relationships were not assessed.

Prairie dogs on each 1-ha plot were counted four times per day. One person counted both plots on the control site and another person counted both plots on the treated site. Observers alternated between sites each day to reduce observer bias. Every count was started on the control site at the south plot, and every count on the treated site at the north plot. This minimised disturbance because alternating the starting plot each day would have required the observer to walk across one plot to reach the other, creating unnecessary disturbance. Counts were adjusted from each time period as described above. 
The four adjusted counts obtained each day for each counting plot were used to obtain the maximum number of pups and adults observed (Fagerstone and Biggins 1986; Severson and Plumb 1998), with the highest number of pups and adults observed each day at each plot then used for analysis. This resulted in daily maximum values for the north and south plots on both the control and treated sites. This produced one estimate for each of the two control plots and two treatment plots.

During late September and October 2008, prairie dogs on both sites were trapped using Tomahawk live traps to collect blood samples and record masses. Trapping took place at this time to maximise yearling development while anticipating the possibility of heavy snow, which could severely impede access to the site. Initially, traps were wired open and pre-baited with control bait for 10 days. During the actual trapping period (6 days over a 15 day period), traps were set between 0830 and 0930 hours each day, and traps were then monitored and prairie dogs collected at least every $2-3 \mathrm{~h}$.

Trapped prairie dogs were dusted with a pyrethrin-based flea powder, weighed with a calibrated spring scale, sexed and assigned to one of two age classes (juvenile or adult) based on their mass (Hoogland 1995, 1996, 2003). Females weighing $<800 \mathrm{~g}$ and males weighing $<900 \mathrm{~g}$ were classified as juveniles, while females and males weighing $\geq 800 \mathrm{~g}$ and $\geq 900 \mathrm{~g}$, respectively, were classified as adults. Mass and age data were subsequently used to determine population structure several months following the pup counts and served as both a secondary estimate of DiazaCon efficacy and an indicator of subsequent population level responses to contraception. A blood sample $(0.1$ to $1.0 \mathrm{~mL})$ was taken from the saphenous or femoral vein of each animal and stored at $4{ }^{\circ} \mathrm{C}$ overnight to allow clotting. Prior to release, a small patch of fur on the ventral surface was dyed with p-phenylene-diamine to allow identification of previously handled animals, which would not be re-sampled. On the day following collection, blood samples were centrifuged and the serum removed and stored at $-70^{\circ} \mathrm{C}$ until analysed. High-performance liquid chromatography was used to determine serum cholesterol and desmosterol concentrations (Johnston et al. 2001).

Analysis of variance (PROC GLM; SAS Institute Inc. 2003) was used to analyse visual counts of pups and adults, pup-toadult ratios, juveniles, juvenile-to-adult ratios and body masses, as well as cholesterol and desmosterol concentrations. Means were compared using Dunnett's test. Counting plots were nested within sites for analysis of visual count data. Treatments were not replicated; therefore, our inferences are restricted to these two sites and not to all possible sites that might have received either treatment. The application of the treatment was the only factor that might have affected animal counts at treated and control sites.

\section{Results}

Treated bait contained $0.170 \pm 0.002 \%$ DiazaCon $(w / w)$. The range was $0.15 \%$ to $0.19 \%$, and the interquartile range was $0.01 \%$. Control bait did not contain detectable levels of DiazaCon.

Table 1 summarises the mean number of pups, adults and pup-to-adult ratios obtained from the visual counts. Significantly fewer pups were sighted on the treated site than on the control site, and the ratio of pups-to-adults was much smaller on the treated site than on the control site.

The mean body masses from the September/October 2008 trapping period are shown in Table 2. The mean weight of all 27 adult males was $1185 \pm 173 \mathrm{~g}$ compared with $1120 \pm 162 \mathrm{~g}$ for all adult females $(n=17)$, regardless of site $\left(\mathrm{F}_{1}=3.98, P=0.053\right)$. Adult prairie dogs from the treated site had a higher body mass than those on the control site $\left(\mathrm{F}_{1}=9.69, P=0.003\right)$. The mean body mass for juvenile males was $730 \pm 41 \mathrm{~g}$ compared with $642 \pm 67 \mathrm{~g}$ for juvenile females $\left(\mathrm{F}_{1}=3.89, P=0.067\right)$. There was no difference in juvenile body masses between sites $\left(\mathrm{F}_{1}=0.06, P=0.816\right)$.

Free serum cholesterol concentrations (Table 3) did not differ between sex $\left(\mathrm{F}_{1}=0.50, P=0.482\right)$ or age classes $\left(\mathrm{F}_{1}=1.82\right.$, $P=0.182)$, but did differ between treated and control animals $\left(\mathrm{F}_{1}=6.26, P=0.015\right)$. The mean overall cholesterol concentration in control animals $\left(411.6 \mu \mathrm{g} \mathrm{mL}^{-1}\right)$ was higher than in treated animals $\left(370.7 \mu \mathrm{g} \mathrm{mL}^{-1}\right)$. Plasma desmosterol concentrations did not differ between sex $\left(\mathrm{F}_{1}=0.73, P=0.395\right)$ or age classes $\left(\mathrm{F}_{1}=0.35, P=0.559\right)$, but did differ between treated and control animals $\left(\mathrm{F}_{1}=5.76, P=0.020\right)$. The mean overall desmosterol

Table 1. Mean ( \pm s.e.m.) visual count data for pups, adults, and pup-toadult ratio obtained from visual counts performed in June and July 2008, on control and treated sites in Fort Collins, $\mathrm{CO}$ $n=$ number of observation days

\begin{tabular}{lrccccccr}
\hline & \multicolumn{9}{c}{ Control } & \multicolumn{2}{c}{ Treated } & & & \\
& Mean & s.e.m. & Mean & s.e.m. & $n$ & \multicolumn{1}{c}{$F$} & df & \multicolumn{1}{c}{$P$} \\
\hline Pups & 15.1 & 1.6 & 1 & 0.2 & 10 & 125.25 & 1 & $<0.001$ \\
Adults & 8.6 & 1.2 & 10.8 & 0.7 & 10 & 3.98 & 1 & 0.063 \\
Pup-to-adult ratio & 2.0 & 0.2 & 0.09 & 0.02 & 10 & 74.11 & 1 & $<0.001$ \\
\hline
\end{tabular}

Table 2. Mean ( \pm s.e.m.) body mass (g) of black-tailed prairie dogs (Cynomys lucovicianus) trapped during September and October 2008 on control and treated sites in Fort Collins, $\mathrm{CO}$

$n=$ numbers of animals

\begin{tabular}{|c|c|c|c|c|c|c|c|c|c|c|c|c|c|c|}
\hline & \multicolumn{7}{|c|}{ Control } & \multicolumn{7}{|c|}{ Treated } \\
\hline & & $\mathrm{F}$ & & & M & & Total & & $\mathrm{F}$ & & & M & & Total \\
\hline & Mean & s.e.m. & $n$ & Mean & s.e.m. & $n$ & $n$ & Mean & s.e.m. & $n$ & Mean & s.e.m. & $n$ & $n$ \\
\hline Juvenile & 637.5 & 25.9 & 8 & 731.3 & 15.5 & 8 & 16 & 662.5 & 37.5 & 2 & 725.0 & & 1 & 3 \\
\hline Adult & 962.5 & 55.4 & 4 & 1109.1 & 46.4 & 11 & 15 & 1169.2 & 40.4 & 13 & 1237.5 & 42.7 & 16 & 29 \\
\hline Combined & 745.8 & 51.6 & 12 & 950.0 & 51.6 & 19 & & 1101.7 & 57.8 & 15 & 1207.4 & 50.2 & 17 & \\
\hline Juv/Adult Ratio & & & & & & & 1.07 & & & & & & & 0.103 \\
\hline
\end{tabular}


Table 3. Mean ( \pm s.e.m.) serum cholesterol and desmosterol concentrations $\left(\mu \mathrm{g} \mathrm{mL}^{-1}\right)$ of black-tailed prairie dogs (Cynomys ludovicianus) trapped during September and October 2008 on control and treated sites in Fort Collins, $\mathrm{CO}$ $\mathrm{ND}=$ not detected

\begin{tabular}{|c|c|c|c|c|c|c|c|c|}
\hline & & & \multicolumn{3}{|c|}{$\begin{array}{c}\text { Cholesterol } \\
\left(\mu \mathrm{gL}^{-1}\right)\end{array}$} & \multicolumn{3}{|c|}{$\begin{array}{c}\text { Desmosterol } \\
\left(\mu \mathrm{gL}^{-1}\right)\end{array}$} \\
\hline & & & Mean & s.e.m. & $n$ & Mean & s.e.m. & $n$ \\
\hline \multirow[t]{4}{*}{ Control } & Juv & F & 403.9 & 33.1 & 9 & ND & ND & 9 \\
\hline & Juv & M & 407.2 & 15.6 & 6 & ND & ND & 6 \\
\hline & $\mathrm{Ad}$ & $\mathrm{F}$ & 428.4 & 20.9 & 5 & ND & ND & 5 \\
\hline & $\mathrm{Ad}$ & M & 412.7 & 28.8 & 11 & 1.0 & 1.0 & 11 \\
\hline \multirow{4}{*}{ Treated } & Juv & $\mathrm{F}$ & 280.0 & 37.0 & 2 & ND & ND & 2 \\
\hline & Juv & $\mathrm{M}$ & 344.0 & & 1 & ND & & 1 \\
\hline & $\mathrm{Ad}$ & F & 393.3 & 11.8 & 13 & 11.3 & 3.4 & 13 \\
\hline & $\mathrm{Ad}$ & M & 365.3 & 22.6 & 16 & 19.9 & 8.8 & 16 \\
\hline
\end{tabular}

concentration in control animals $\left(0.35 \mu \mathrm{g} \mathrm{mL}^{-1}\right)$ was substantially lower than in treated animals $\left(14.5 \mu \mathrm{g} \mathrm{mL}^{-1}\right)$.

\section{Discussion}

The ratio of pups per adult (0.09 versus 2.0$)$ was $95.5 \%$ lower on the DiazaCon-treated site compared with the control site. This is much greater than the $47 \%$ difference achieved by Nash et al. (2006). In black-tailed prairie dogs, testosterone peaks around the end of December (Knowles 1987; Hoogland 1995). Nash et al. (2006) did not bait until February, after testosterone had peaked in males. Sperm production was probably not impaired in these males, and females likely had already undergone ovarian follicular development by the time DiazaCon took effect. In the current study, DiazaCon was applied a month before peak testosterone levels in males, so spermatogenesis was probably inhibited. Similarly, females most likely did not undergo ovarian follicular development. Earlier treatment probably resulted in higher efficacy.

The ratio of juveniles per adult $(0.103$ versus 1.07$)$ was $90.4 \%$ lower on the treated site than on the control site, somewhat lower than the efficacy indicated by the ratio of pups to adults 3 months earlier ( 0.09 versus 2.0$)$. This could be due to the difficulty of assigning borderline animals to an age group using body mass. When prairie dogs weighed close to the cutoff weight between juveniles and adults, it was difficult to assign them to an age class. Post-parturition females in particular can weigh roughly similar to an older juvenile (Hoogland 1995, 2003). Some animals that were classified as juveniles might have actually been adults.

The number of adults on the control and treated sites was similar when pups first emerged from burrows in June and July, but the number of adults on the treated site was nearly twice that of the control site in September-October 2008, with much of the increase being due to a 3 -fold greater number of adult females on the treated plots compared to the control plots.

This difference may have resulted from immigration from untreated areas. However, dispersal is usually male-biased (Hoogland 1995), much more prevalent in yearling males ( $\geq 8$ months but $\leq 20$ months after emergence) than adult males (Hoogland 1995) and occurs most commonly in early to mid-June, which would preclude movement by young-of-the- year in this study. Most females remain in the coterie in which they were born for their entire life (Hoogland 1995). Over time, a coterie's home territory usually remains roughly constant. However, the number of prairie dogs within the coterie can be highly variable so that prairie dog density within a coterie territory can vary substantially (Hoogland 1995). The increase in adult males and females observed in this study over a 2-3 month period is highly unusual and has not been previously reported (J. Hoogland, pers. comm.)

This study involved a relatively small, local colony. A largerscale study, in which entire populations are treated, treatments are replicated and all animals individually marked from the outset, is warranted, and could eliminate dispersal and immigration as potentially confounding factors. Additionally, the inferences made herein are specific to the two treatment sites and we do not extrapolate our findings to the population or geographic level. The proximity and similarity of the two treatment sites provided reasonable assurance that resulting differences were due to the treatment.

Adult male and female prairie dogs on the treated site weighed significantly more than those on the control site, and there are likely several reasons for this. Treated females may have weighed more because (1) they did not experience the physiological demands of pregnancy and lactation, and (2) they likely had more time to forage because they were not raising a litter. An even greater factor in the observed weight gain in treated prairie dogs may have been a result of the treatment itself. As discussed previously, DiazaCon reduces the production of steroid hormones necessary for successful gonadal function and subsequent reproduction, and the reduction/elimination of these hormones through treatment may result in a temporary condition similar to castration or ovariectomy. Castrated male prairie dogs in Colorado weighed more than control males (Schwartz 2002). Domestic animals that are spayed or neutered tend to gain body mass (Houpt et al. 1979; Fettman et al. 1997). Hormonal changes might be partially responsible for the increased body mass (Wallen et al. 2002; Martin et al. 2006). The body mass results are consistent with another prairie dog field study using a different contraceptive agent (Yoder, unpubl. data). An unintended benefit of annual contraception may be that increased body mass of treated animals might correspond to a higher over-winter survival rate, although the current study did not address this question. Sterilisation of ricefield rats (Rattus argentiventer), European rabbits (Oryctolagus cuniculus) and brushtail possums (Trichosurus vulpecula) resulted in increased survival of sterilised females (Twigg et al. 2000; Jacob et al. 2004; Ramsey 2005; Williams et al. 2007). Immunocontraception of wild mares also resulted in increased longevity (Kirkpatrick and Turner 2007).

Serum cholesterol concentrations from blood sampled in the autumn were $10 \%$ lower in prairie dogs from the treated site than from the control site. Previous studies using DiazaCon in birds showed cholesterol must be decreased by $\sim 40 \%$ to impair reproduction (Yoder et al. 2005). Results from studies using mice and rats were equivocal (Nash, unpubl. data), and data are not available to determine how much cholesterol must be reduced to impair reproduction in small mammals. However, the small difference in cholesterol concentrations indicated 
that treated animals would likely be able to produce litters the following breeding season.

Chemical analysis showed that the actual percentage of DiazaCon present in bait was lower than the target of $0.22 \%$ DiazaCon $\left(\mathrm{w} \mathrm{w}^{-1}\right)$. Even so, the dose used was effective, indicating that a lower dose could be used. The target dose was $50 \mathrm{mg}$ DiazaCon $\mathrm{kg}^{-1}$ body mass day ${ }^{-1}$ per animal, whereas the actual dose received was $\sim 38 \mathrm{mg}$ DiazaCon $\mathrm{kg}^{-1}$ body mass day ${ }^{-1}$ per animal. This estimate was based on each animal consuming $22.5 \mathrm{~g}$ of bait day $^{-1}$ and an average body mass of $1.0 \mathrm{~kg}$. The possibility of overdosing was probably very small. Hambourger and Martinez (1968) treated adult male Sprague Dawley rats with increasing intragastric DiazaCon doses ranging from 40 to $700 \mathrm{mg} \mathrm{kg}^{-1}$ and calculated the LD50 as $470 \pm 44 \mathrm{mg} \mathrm{kg}^{-1}$ with lethality beginning at $300 \mathrm{mg} \mathrm{kg}^{-1}$. In the current study, this would have required a single prairie dog to consume the entire bait aliquots of eight separate mounds, an unlikely event.

Further studies need to be conducted to reduce risks to nontarget animals, such as mice, rabbits, birds and snakes, which might consume the bait. Such studies would determine the lowest effective dose, and whether prairie dogs would eat bait placed in their burrows. The risk to predators consuming DiazaCon-treated prairie dogs should also be assessed. Studies are needed to determine the effect of contraception on the social structure of the colony.

Results from this study indicate that DiazaCon is an effective reproductive inhibitor in prairie dogs on the local sites tested, and has promise as an effective tool for the management of prairie dog populations.

\section{Acknowledgments}

Chirstina Denny and Lauren O'Dell provided assistance in the field. John Eisemann, Jeanette O'Hare, Douglas Eckery and Lowell Miller provided comments on the manuscript. Justin Fischer provided GIS-based data to define the plots. We also thank John Hoogland for his invaluable comments and manuscript additions.

\section{References}

Andelt, W. F., and Hopper, S. N. (1998). Managing prairie dogs. Colorado State University Cooperative Extension Bulletin Number 6.506, Fort Collins, CO.

Kotliar, N. B., Baker, B. W., Whicker, A. D., and Plumb, G. (1999). A critical review of assumptions about the Prairie dog as a keystone species. Environmental Management 24, 177-192.

Collins, A. R., Workman, J. P., and Uresk, D. W. (1984). An economic analysis of black-tailed prairie dog (Cynomys ludovicianus) control. Journal of Range Management 37, 358-361. doi:10.2307/3898711

Cully, J. F. Jr. (1997). Growth and life-history changes in Gunnison's prairie dogs after a plague epizootic. Journal of Mammalogy 78, 146-157. doi: $10.2307 / 1382647$

Emmons, G. T., Rosenblum, E. R., Peace, J. N., Malloy, J. M., Doerfler, D. L., McManus, I. R., and Campbell, I. M. (1982). Effects of 20,25diazacholesterol on cholesterol synthesis in cultured chick muscle cells: a radiogas chromatographic and mass spectrometric study of the post-squalene sector. Biomedical Mass Spectrometry 9, 278-285. doi: $10.1002 /$ bms. 1200090703

Fagerstone, K. A., and Biggins, D. E. (1986). Comparison of capturerecapture and visual count indices of prairie dog densities in blackfooted ferret habitat. Great Basin Naturalist Memoirs 8, 94-98.
Fettman, M. J., Stanton, C. A., Banks, L. L., and Hamar, D. W. (1997). Effects of neutering on bodyweight, metabolic rate and glucose tolerance of domestic cats. Research in Veterinary Science 62, 131-136. doi:10.1016/ S0034-5288(97)90134-X

Fort Collins Natural Resources Division (1998). Prairie dog policy for city natural areas. Fort Collins Natural Resources Division, Fort Collins, CO.

Franklin, W. L., and Garrett, M. G. (1989). Nonlethal control of prairie dog colony expansion with visual barriers. Wildlife Society Bulletin 17, 426-430.

Graves, R. A. (2001). 'The Prairie Dog: Sentinel of the Plains.' (Texas Tech University Press: Lubbock, TX.)

Hambourger, W., and Martinez, T. (1968) Acute toxicity studies in mice and rats and emesis in dogs: Laboratory Project ID SC-12937. Unpublished study prepared by G.D. Searle \& Co. 7 p.

Hoogland, J. L. (1995). 'The Black-Tailed Prairie Dog: Social Life of a Burrowing Mammal.' (University of Chicago Press: Chicago, IL.)

Hoogland, J. L. (1996). Cynomys ludovicianus. Mammalian Species $\mathbf{5 3 5}$, 1-10. doi:10.2307/3504202

Hoogland, J. L. (2003). Sexual dimorphism of prairie dogs. Journal of Mammalogy 84(12), 4-1266.

Houpt, K. A., Coren, B., Hintz, H. F., and Hildebrant, J. E. (1979). Effect of sex and reproductive status on sucrose preference, food intake and body weight of dogs. Journal of the American Veterinary Medical Association 174, 1083-1108.

Hygnstrom, S. (1996). Plastic visual barriers were ineffective at reducing recolonization rates of prairie dogs. In 'Proceedings of the 12th Great Plains Wildlife Damage Control Workshop'. (Eds D. L. Nolte, W. M. Arjo and D. Stalman.) pp. 74-76. (University of Nebraska: Lincoln, NE.)

Hygnstrom, S. E., and Virchow, D. R. (1994). Prairie dogs. In 'Prevention and Control of Wildlife Damage'. (Eds S. E. Hygnstrom, R. M. Timm and G. E. Larson.) pp. B-85-96. (University of Nebraska, Great Plains Agricultural Council, USDA/APHIS/WS.)

Jacob, J., Herawati, N. A., Davis, S. A., and Singleton, G. R. (2004). The impact of sterilized females on enclosed populations of ricefield rats. The Journal of Wildlife Management 68, 1130-1137. doi:10.2193/0022541X(2004)068[1130:TIOSFO]2.0.CO;2

Johnson, W. C., and Collinge, S. K. (2004). Landscape effects on blacktailed prairie dog colonies. Biological Conservation 115, 487-497. doi:10.1016/S0006-3207(03)00165-4

Johnston, J. J., Goodall, M. J., Hurley, J. C., Yoder, C. A., and Miller, L. A. (2001). Determination of DiazaCon in quail feed and quail serum by ion pair reversed-phase chromatography. Journal of AOAC International 84, 634-639.

Johnston, J. J., Goodall, M. J., Yoder, C. A., Furcolow, C. A., Goldade, D. A., Kimball, B. A., and Miller, L. A. (2003). Desmosterol: a biomarker for the efficient development of 20,25-diazacholesterol as a contraceptive for pest wildlife. Journal of Agricultural and Food Chemistry 51, 140-145. doi:10.1021/jf020731d

Kirkpatrick, J. F., and Turner, A. (2007). Immunocontraception and increased longevity in equids. Zoo Biology 26, 237-244. doi:10.1002/ zoo.20109

Knowles, C. J. (1986). Population recovery of black-tailed prairie dogs following control with zinc phosphide. Journal of Range Management 39, 249-251. doi: 10.2307/3899060

Knowles, C. J. (1987). Reproductive ecology of black-tailed prairie dogs in Montana. The Great Basin Naturalist 47, 202-206.

Kotliar, N. B., Baker, B. W., Whicker, A. D., and Plumb, G. (1999). A critical review of assumptions about the prairie $\operatorname{dog}$ as a keystone species. Environmental Management 24, 177-192.

Lybecker, D., Lamb, B. L., and Ponds, P. D. (2002). Public attitudes and knowledge of the black-tailed prairie dog: a common and controversial species. Bioscience 52(7), 607-613. doi:10.1641/00063568(2002)052[0607:PAAKOT]2.0.CO;2 
Magle, S. B., and Crooks, K. R. (2009). Investigating the distribution of prairie dogs in an urban landscape. Animal Conservation 12, 192-203. doi:10.1111/j.1469-1795.2009.00237.x

Magle, S. B., McClintock, B. T., Tripp, D. W., White, G. C., Antolin, M. F., and Crooks, K. R. (2007). Mark-resight methodology for estimating population densities for prairie dogs. The Journal of Wildlife Management 71, 2067-2073. doi:10.2193/2006-138

Martin, L. J., Siliart, B., Dumon, H. J., and Nguyen, P. (2006). Spontaneous hormonal variations in male cats following gonadectomy. Journal of Feline Medicine and Surgery 8, 309-314. doi:10.1016/j.jfms.2006. 03.002

Massei, G., Quy, R. J., Gurney, J., and Cowan, D. P. (2010). Can translocations be used to mitigate human-wildlife conflicts? Wildlife Research 37, 428-439. doi:10.1071/WR08179

Menkens, G. E. Jr, Biggins, D. E., and Anderson, S. H. (1990). Visual counts as an index of white-tailed prairie dog density. Wildlife Society Bulletin 18, 290-296.

Miller, B., Wemmer, C., Biggins, D., and Reading, R. (1990). A proposal to conserve black-footed ferrets and the prairie dog ecosystem. Environmental Management 14, 763-769. doi:10.1007/BF02394170

Miller, B., Ceballos, G., and Reading, R. (1994). The prairie dog and biotic diversity. Conservation Biology 8, 677-681. doi:10.1046/j.1523-1739. 1994.08030677.x

Miller, B., Reading, R., Hoogland, J., Clark, T., Ceballos, G., List, R., Forrest, S., Hanebury, L., Manzano, P., Pacheco, J., and Uresk, D. (2000). The role of prairie dogs as a keystone species: response to Stapp. Conservation Biology 14, 318-321. doi:10.1046/j.1523-1739.2000.99201.x

Nash, P. B., Furcolow, C. A., Bynum, K. S., Yoder, C. A., Miller, L. A., and Johnston, J. J. (2006). 20,25-Diazacholesterol as an oral contraceptive for black-tailed prairie dog population management: a pilot study. Human-Wildlife Conflicts 1, 60-67.

Ramsey, D. (2005). Population dynamics of brushtail possums subject to fertility control. Journal of Applied Ecology 42, 348-360. doi:10.1111/j.1365-2664.2005.01006.x

Robinette, K. W., Andelt, W. F., and Burnham, K. P. (1995). Effect of group size on survival of relocated prairie dogs. The Journal of Wildlife Management 59, 867-874. doi:10.2307/3801968

Schwartz, A. M. (2002). Surgical sterilization of the black-tailed prairie $\operatorname{dog}$ (Cynomys ludovicianus): A model for the behavioral effects of reproductive inhibition and hormonal reduction. Thesis, Colorado State University, Fort Collins, CO.

Severson, K. E., and Plumb, G. E. (1998). Comparison of methods to estimate population densities of black-tailed prairie dogs. Wildlife Society Bulletin 26, 859-866.
Truett, J., Dullman, J., Matchett, M., Owens, E., and Seery, E. (2001). Translocating prairie dogs: a review. Wildlife Society Bulletin 29, 863-872.

Twigg, L. E., Lowe, T. J., Martin, G. R., Wheeler, A. G., Gray, G. S., Griffin, S. L., O'Reilly, C. M., Robinson, D. J., and Hubach, P. H. (2000). Effects of surgically imposed sterility on free-ranging rabbit populations. Journal of Applied Ecology 37, 16-39. doi:10.1046/ j.1365-2664.2000.00471.x

Wallen, W. J., Belanger, M. P., and Wittnich, C. (2002). Body weight and food intake profiles are modulated by sex hormones and tamoxifen in chronically hypertensive rats. The Journal of Nutrition 132, 2246-2250.

Williams, C. K., Davey, C. C., Moore, R. J., Hinds, L. A., Silvers, L. E., Kerr, P. J., French, N., Hood, G. M., Pech, R. P., and Krebs, C. J. (2007). Population responses to sterility imposed on female European rabbits. Journal of Applied Ecology 44, 291-301. doi:10.1111/j.1365-2664. 2006.01264.x

Witmer, G. W., VerCauteren, K. C., Manci, K. M., and Dees, D. M. (2000). Urban-suburban prairie dog management: opportunities and challenges. In 'Proceedings of the 19th Vertebrate Pest Conference'. (Eds T. P. Salmon and A. C. Crabb.) pp. 439-444. (University of California: Davis, CA.)

Witmer, G., Gionfriddo, J., and Pipas, M. (2008). Evaluation of physical barriers to prevent prairie dog colony expansion. Human-Wildlife Conflicts 2, 206-211.

Yoder, C. A., Andelt, W. F., Miller, L. A., Johnston, J. J., and Goodall, M. J. (2004). Effectiveness of twenty, twenty-five diazacholesterol, avian gonadotropin-releasing hormone, and chicken riboflavin carrier protein for inhibiting reproduction in Coturnix quail. Poultry Science 83, 234-244. doi:10.1093/ps/83.2.234

Yoder, C. A., Bynum, K. S., and Miller, L. A. (2005). Development of DiazaCon $^{\mathrm{TM}}$ as an avian contraceptive. In 'Proceedings of the 11 th Wildlife Damage Management Conference'. (Eds D. L. Nolte and K. A. Fagerstone.) pp. 190-201. (University of Nebraska: Lincoln, NE.)

Yoder, C. A., Mayle, B. A., Furcolow, C. A., Cowan, D. P., and Fagerstone, K. A. (2011). Fedding of grey squirrels (Sciurus carolinensis) with the contraceptive agent DiazaCon ${ }^{\mathrm{TM}}$ : effect on cholesterol, hematology, and blood chemistry. Integrative Zoology 6, 409-419. doi:10.1111/ j.1749-4877.2011.00247.x

Zinn, H. C., and Andelt, W. F. (1999). Attitudes of Fort Collins, Colorado, residents toward prairie dogs. Wildlife Society Bulletin 27, 1098-1106. 